\title{
FOSTERING THE MEDIATING ROLE OF THE FEELING OF BELONGING TO AN ORGANIZATION AMONG ROMANIAN MEMBERS OF GENERATION Z
}

\section{Elena Botezat}

University of Oradea, Romania

E-mail:elenabotezat1@gmail.com

\section{Silvia L. Fotea}

Emanuel University of Oradea, Romania

E-mail: silvia.fotea@emanuel.ro

\section{Marius Marici}

Stefan cel Mare University Suceava, Romania

E-mail:maricimarius@yahoo.com

\author{
Ioan S. Fotea* \\ Emanuel University of Oradea, Romania \\ E-mail: ioan.fotea@emanuel.ro
}

(Received: July 2020; Accepted: September 2020; Published: October 2020)

\begin{abstract}
The addition of Generation Z/Centennials to the workplace landscape will bring about new challenges for the management of any organization. To tackle the changing work environment and workforce, we conducted a survey-based empirical exploratory study among students in economics from two universities located in the western part of Romania. Our study proposes an alternative view of the motivational potential, including the feeling of belonging to an organization in work settings. The aim was to explore the potential for the feeling of belonging to play the role of mediator between four distinct career attitudes and the turnover intention in the specific case of Romanian Generation $\mathrm{Z}$ members. Additionally, we investigated which variables are significant predictors for the feeling of belonging to an organization. The results indicate that is efficient to invest in creating belongingness for those Generation $\mathrm{Z}$ members inclined towards making moves between jobs and organizations (OMPA), for those who present the mental capacity to be mobile (BMA) and for those who can be adaptive in terms of performance and learning demands (SDA). For those Romanian Generation Z
\end{abstract}

*Corresponding author: Ioan S. Fotea. E-mail: ioan.fotea@emanuel.ro

Copyright (C) 2020 The Author(s). Published by VGWU Press

This is an Open Access article distributed under the terms of the Creative Commons BY 4.0 license (Creative Commons - Attribution 4.0 International - CC BY 4.0) which permits unrestricted use, distribution, and reproduction in any medium, provided the original author and source are credited. 
Botezat, E., Fotea, S.L., Marici, M., Fotea, I.S. (2020)

Fostering the mediating role of the feeling of belonging to an organization among Romanian members of Generation Z

members who use their internal values to provide guidance and measure for success, including the feeling of belonging to an organization in work settings seems to be inefficient.

Keywords: Generation Z, Romania, career attitude, feeling of belonging, turnover intention

JEL classification: M10, M12

\section{Introduction}

Since joining the European Union, Central and Eastern European countries have lost many workers (Dodescu et al., 2018); its loss is quantified at 3.4 million workers. In the wealthiest part of Europe, the same workers were satisfied to the extent that their work gave them good salaries and job security (Paunescu \& Molnar, 2016). For young people, especially those born between 1996 and 2012, known as Generation Z or Centennials, but also called I Gen or eGen (Gaidhani et al., 2019), these things are not enough. Generation $Z$ has a strong need for empowerment and flexible working conditions and is highly concerned about satisfying safety and belonging needs (Ferincz et al., 2011). Data shows that in 2019, Centennials, this new generation outnumbered the previous generation named Millennials, accounted at 32 percent of the total global population (Gherini, 2018; Insider, 2018; Miller \& Lu, 2018). Now, in 2020, Generation Z members have just finished their education and are about to enter the workplace. But the length of time that they will spend in an organization, a job, or an activity is undeterminable due to different reasons (Chicca \& Shellenbarger, 2018).

Centennials, who are considered to be the true digital natives, live in a faster rhythm than the previous generations and don't want to be stuck in one place (Igel \& Urquhart, 2012; Spears et al., 2015). They are characterized as the snowflake generation due to parenting philosophy and methods which "denied resiliencebuilding freedoms that past generations enjoyed" (Fox, 2016). Highly connected, they tend to be more individualistic and self-directed. They have seen their parents struggle through the economic recession. Therefore, they are less likely to take financial risks and are looking for reliable, secure jobs (Turner, 2015; Wiedmer, 2015; Chicca \& Shellenbarger, 2018). All these, in our opinion, strengthen trends related to younger generation turnover intention identified in previous researches. For example, Martin and Schmidt (2010), find that one in four employees intends to leave his/her workplace within one year, one in three high-potential employees admits to not putting all his/her effort into her/his job, and one in five employees believes his/her aspirations are quite different from what the organization has planned for him/her. If this is the picture for previous generations, things tend to

70 S sciendo Studia Universitatis "Vasile Goldis" Arad. Economics Series Vol 30 Issue 4/2020 ISSN: 1584-2339; (online) ISSN: 2285 - 3065

Web: publicatii.uvvg.ro/index.php/studiaeconomia. Pages $69-91$ 
Botezat, E., Fotea, S.L., Marici, M., Fotea, I.S. (2020)

Fostering the mediating role of the feeling of belonging to an organization among Romanian members of Generation Z

become worse when we are talking about Generation $\mathrm{Z}$, and it seems that organizations aren't keeping up with these new workforce demands. More and different requirements in the context of a dramatic decrease in the number of young people. According to the European Union's statistics branch Eurostat, from 1990 until 2016, Hungary has lost 14 percent from its young people segment (those aged between 15 and 29), Slovakia 19 percent, the Czech Republic 19 percent, Poland 21 percent and Romania 33 percent. This new addition of Centennials to the workplace landscape will bring about new challenges for employers since the context of Gen-Z' upbringing will generate a specific set of behaviors at work and unique expectations, aspirations, and motivations from their jobs. Can we become better at creating workplace experiences, not only reducing stress factors?

The literature in the field focuses on sources of employees' turnover, effects of turnover, and strategies to minimize the employees' turnover. Our study comes to enrich the research related to strategic components that can reduce the possible turnover intention in the field of management literature related to Generation Z members. Therefore, the primary purpose of our study is to examine the mediating role of the feeling of belonging to an organization between career attitude and turnover intention within Generation Z, also known as Centennials. The study of this new addition to the workplace landscape is essential and timely if we add that human resource specialists agree that Generation $\mathrm{Z}$ places a higher focus on the cultural fit to their jobs than all the other generations before them (Buhler \& Evans, 2018).

To gain a more detailed and accurate understanding, we extend our research to find out which variables included in our study are significant predictors for the feeling of belonging to an organization.

The paper is structured in three main sections. The first section provides a theoretical background on career attitude, turnover intention, and the role of the feeling of belonging to an organization as a mediator and its predictors. The second one explains the methodology used in this research, while the third section presents the data analysis and results obtained. Conclusions, limitations, and directions for future research are offered at the end of the paper.

\section{Conceptual background and hypothesis enhancement}

\subsection{Career attitude - an answer to the challenges}

Traditionally career, "the evolving sequence of a person's work experiences over time" (Arthur et al., 1989), was defined by the employer-employee relationship. The contemporary career, according to Sullivan and Baruch (2009) is more and more different due, on the one hand, to environmental changes (e.g., rapid 
Botezat, E., Fotea, S.L., Marici, M., Fotea, I.S. (2020)

Fostering the mediating role of the feeling of belonging to an organization among Romanian members of Generation Z

technological advancements, increased workforce diversity) and, on the other hand, to the individual's response and behavior changes (e.g. women and men who are taking a break from the workforce to become the primary caregiver or children). Based on their extensive review of the literature, Sullivan and Baruch (2009) define a career "as an individual's work-related and other relevant experiences, both inside and outside of organizations, that form a unique pattern over the individual's life span". More adequate to the new realities, this definition recognizes both physical and psychological movements, and additionally career alternatives and outcomes. Individuals, especially members of the Millennials and the Generation Z/Centennials, are driven more by their career perceptions and interpretations than by organizational career management practices. Arthur and Rousseau (2001) and Hall (2004) point out that individuals are adapting to a more transactional employer-employee relationship and taking more responsibility for their career development. In these conditions, the idea to develop strategies and practices to tackle the changing work environment and workforce (Feldman \& Leana, 2000; Youssef \& Luthans, 2007; Inkson, 2008) is not the best solution. Literature shows that the career perspective is linked with two concepts: the protean career attitude (Hall, 1976, 2004; Briscoe \& Hall, 2006) and the boundaryless career attitude (Arthur, 1994; Arthur \& Rousseau, 2001; Defillippi \& Arthur, 1994), each of them defined by two components. Based on these, in our study we used the four components identified by scholars (Briscoe \& Hall, 2006; Defillippi \& Arthur, 1994): (1) self-directed attitude, which means that the person can be adaptive in terms of performance and learning demands; (2) value-driven attitude in the sense that the person's internal values provide the guidance and measure of success; (3) boundaryless mindset attitude which refers to an individual's mental ability to be mobile and (4) organizational mobility preference attitude, which indicates the attitude to navigate moves between different occupations, jobs, and organizations.

\subsection{Turnover intention - a response to dynamism and uncertainty}

Turnover intention is the disposition of thinking and planning to leave an organization, a job, or a profession voluntarily. Models proposed by different scholars (Price \& Mueller, 1981; Parasuraman, 1989; Udechukwu \& Mujtaba, 2007; Awan \& Anjam, 2014) indicate that turnover intention is a complex and a multistage social, economic and psychological process. The turnover intention has an impact on the organization in terms of costs, effectiveness, productivity, and on the employee as well because individuals may lose financial benefits, selfconfidence, and, maybe, the satisfaction of life. In a review of determinants of employee turnover intention, Jha (2009) classifying them into two broad categories

72 Sciendo Studia Universitatis "Vasile Goldis" Arad. Economics Series Vol 30 Issue 4/2020 ISSN: 1584-2339; (online) ISSN: 2285 - 3065

Web: publicatii.uvvg.ro/index.php/studiaeconomia. Pages $69-91$ 
Botezat, E., Fotea, S.L., Marici, M., Fotea, I.S. (2020)

Fostering the mediating role of the feeling of belonging to an organization among Romanian members of Generation Z

viz. individual factors and organizational factors. According to the previously mentioned author, individual factors refer to personal characteristics ingrained in individuals and to learned characteristics. In contrast, organizational factors take into account job stress, social comparison, nature of work, opportunities for professional growth, collegial relations, pay satisfaction, organizational culture. In their studies on turnover intention, some scholars used different intermediary variables, which may be considered as mediating factors. In a study of bank employees, Fan, Ji and Shao cited by Xiong, Ye and Wang (2017) found a positive correlation between the psychological contract perceived by respondents and turnover intention. Another study conducted by Riaz, Shah and Amanat (2013) shows that work engagement partially mediates between emotional exhaustion, cynicism, and turnover intention. The same mediator, work engagement, was indicated by Lee, Idris and Tuckey (2019) for the relationships of both supervisory coaching and performance feedback to turnover intention. Gabel Shemueli, Dolan, Suárez Ceretti and Nuñez Del Prado (2016) found that burnout fully mediates the relationship between work overload and turnover intention. In contrast, work engagement partially mediates the relationship between social support and turnover intention. The affective commitment was identified as a full mediator in the study of Kartika and Purba (2018). Syed, Aleena, Ahmand, Muhamad Bilal, Hafiz Fawad Ali and Amna Gohar (2018) took job stress as a mediator in their study related to the relationship between work-family conflicts of female doctors and turnover intention.

\subsection{Feeling of belonging as a potential mediator}

According to Rigby and Ryan (2018), to feel we belong and "matter" to others is one of our primary needs. As Kelly (2001) points out, few contacts are enough for people with a lower need to belong, while others, at the opposite end, need many such contacts. The need for relatedness "encompasses a person's striving to relate to and care for others, to feel that those others are relating authentically to one's self, and to feel a satisfying and coherent involvement with the social world more generally" (Deci \& Ryan, 1991). Baumeister and Leary (1995) called this "need for belongingness" and showed that it is more than the need for social contact. In their research, they thought about the need for positive and pleasant social contacts within the context of desired relationships with people other than strangers and point out that the need for belongingness is satisfied by an interpersonal bond marked by "stability, affective concern, and continuation into the foreseeable future" (Baumeister \& Leary, 1995). Given that "the need for relatedness is the need for experiencing belongingness" (Osterman, 2000), relatedness and belongingness were used interchangeably throughout this paper. 
Botezat, E., Fotea, S.L., Marici, M., Fotea, I.S. (2020)

Fostering the mediating role of the feeling of belonging to an organization among Romanian members of Generation Z

Since the need for belongingness leads to physical, emotional, behavioral, and mental well-being (Maslow, 1968), this variable can contribute to explaining a variety of human behavior, including turnover intention. Several studies (Finn, 1989; Goodenow, 1992; Furrer and Skinner, 2003); Deci \& Ryan, 1991; Osterman, 2000) show that the feeling of belonging is one of the most important elements for all students to function well in all types of learning environments, the organizational context is one of these. We want to underline here that research related to feeling of belonging among students has been conducted in diverse ways, which affects the accumulation of research findings. What stands out is that an important number of studies claimed that retention and success are influenced by sociological and psychological considerations, augmented by economic factors. For example, Bers and Smith (1991) found that social integration had a more significant effect on student retention than academic integration among college students. Effects that academic study had on students enrolled in first and second cycle programs revealed, in the research conducted by Blais and Pulido (1992) that the major differences between the two groups (one from a university in Canada and the other from a university in Venezuela) lie in family, social life and leisure.

All these aspects encourage us to use in our study the feeling of belonging to an organization as a mediator between Generation Z's career attitude and turnover intention.

The management literature related to the added value created by the feeling of belonging to an organization needs and requires empirical evidence. Our study attempts to fill a part of this. Since the feeling of belonging to an organization is among the least well-understood concept in the economic field, another research question appears: "Which variables included in our study are predictors for the feeling of belonging to an organization within Generation Z/Centennials?"

\section{Research methodology and data}

The central objective of this study is to explore the potential for the feeling of belonging to an organization to play the role of a mediator between four distinct career attitudes and the possible turnover intention in the specific case of Centennial generation. The related objective is to investigate if these four attitudinal career variables are significant predictors for the feeling of belonging to an organization.

Given the context described above, we propose the following research hypothesis to be investigated in this study:

H1. The feeling of belonging to an organization mediates the relationship between self-directed attitude and Centennials possible turnover intention.

74 S sciendo Studia Universitatis "Vasile Goldis" Arad. Economics Series Vol 30 Issue 4/2020 ISSN: 1584-2339; (online) ISSN: $2285-3065$

Web: publicatii.uvvg.ro/index.php/studiaeconomia. Pages $69-91$ 
Botezat, E., Fotea, S.L., Marici, M., Fotea, I.S. (2020)

Fostering the mediating role of the feeling of belonging to an organization among Romanian members of Generation Z

H2. The relationship between value-driven attitude and Centennials' possible turnover intention is mediated by the feeling of belonging to an organization.

H3. The feeling of belonging to an organization mediates the relationship between boundaryless mindset attitude and Centennials possible turnover intention.

H4. The relationship between organizational mobility preference attitude and Centennials' possible turnover intention is mediated by the feeling of belonging to an organization.

H5. All four attitudinal career variables are predictors of the feeling of belonging to an organization.

This endeavor is encapsulated in our proposed research model shown in Figure 1.

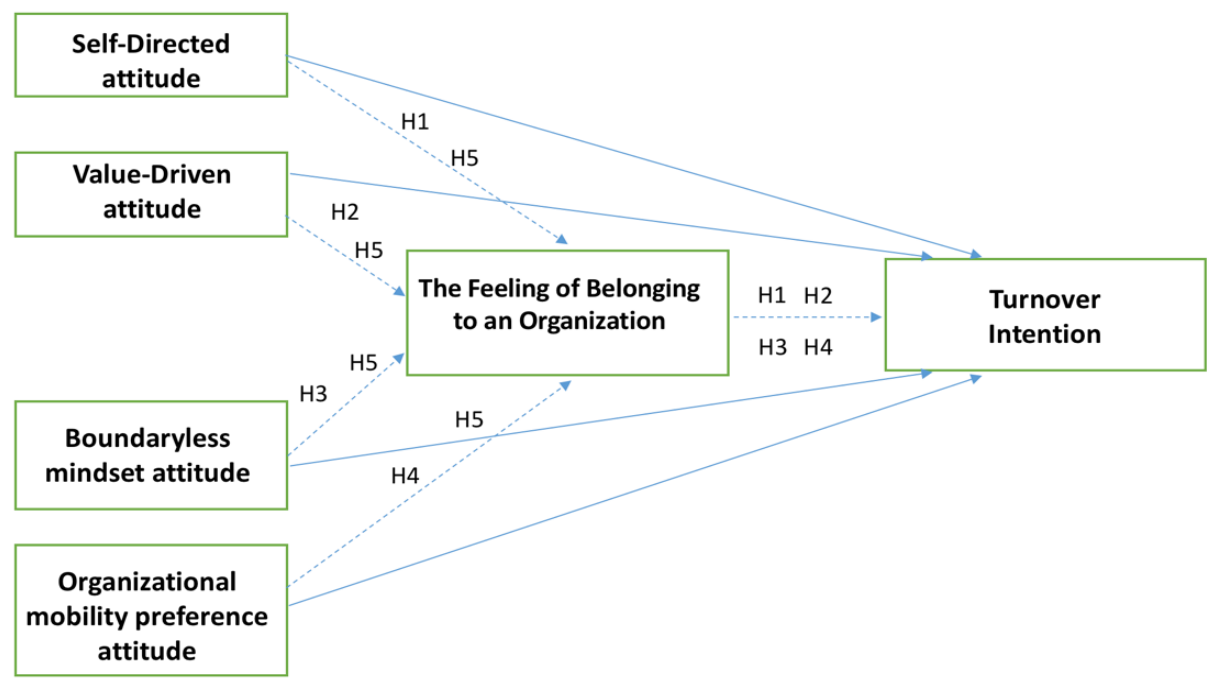

Figure 1 The Visual Representation of all moderation relationships to be analyzed

As depicted in Figure 1, the variable the feeling of belonging to an organization is placed centrally between the four career attitude components and possible turnover intention of Generation Z/Centennials. Nevertheless, the data analysis will also explore the direct relationship between the four components of the variable career attitude and variable turnover intention.

\subsection{Variables measurements and operationalization of concepts}

To meet the objectives of this study and to test the formulated hypothesis, a survey- 
Botezat, E., Fotea, S.L., Marici, M., Fotea, I.S. (2020)

Fostering the mediating role of the feeling of belonging to an organization among Romanian members of Generation Z

based questionnaire exploratory study was designed and conducted. To develop the data collection instrument, each variable included in the conceptual model was operationalized based on scales identified in the literature, which were accepted and validated in other studies exploring similar themes.

The four variables measuring the career attitude of Centennials, namely selfdirected attitude, value-driven attitude, boundaryless mindset attitude, organizational mobility preference attitude, were operationalized based on the scales developed and validated by Briscoe et al. (2006). The self-directed attitude scale (SDA) included eight items aimed to measure the person's ability to be adaptive in terms of performance and learning demands. The value of the Standardized Alpha Coefficient obtained for SDA scale was 0.833. The valuedriven attitude (VDA) was operationalized using five items that measure the extent to which the individual draws upon and uses his internal values to provide guidance and measure for success. The Standardized Alpha Coefficient for the VDA scale was 0.801 . The boundaryless mindset attitude (BMA) scale measuring the person's psychological mobility, namely his/her mental ability to be mobile, was operationalized using six items, and the Standardized Alpha Coefficient obtained for it was 0.890 . The organizational mobility preference attitude (OMPA) scale was operationalized with four items measuring the person's physical mobility, namely its attitude towards making actual moves between jobs or organizations. The Standardized Alpha Coefficient for the OMPA scale was 0.819. The final instrument measuring the variable career attitude included a total of 23 items.

An essential mention regarding these constructs is that they describe attitudes rather than vocational behavior (Volmer \& Spurk, 2011). Also, given the fact that the participants in our study were undergraduate students who may not have had an actual job at the moment of research, the original wording of the items was slightly adapted to fit our research purpose.

All items in these career attitude scales were presented on a 5-point scale anchored at 1 (totally disagree) and 5 (totally agree). Subjects were asked to indicate the extent to which they agree with the presented statements using this response scale. The specific items representing these four scales are presented in Table 1.

The proposed mediator variable, namely the feeling of belonging to an organization $(F B O)$, was operationalized using six items which aimed to evaluate the feelings of belonging of our respondents both at an organizational level and also at the level of human relations (relations with work colleagues). The items used to measure this variable were selected from the extensive research and proposed scales in The Copenhagen Psychosocial Questionnaire II (Burr et al., 2010; Pejtersen et al., 2010). All six items forming this scale were evaluated on a 5 -point scale anchored at 1 (not at all important) and 5 (very important).

76 Sciendo Studia Universitatis "Vasile Goldis" Arad. Economics Series Vol 30 Issue 4/2020 ISSN: 1584-2339; (online) ISSN: $2285-3065$

Web: publicatii.uvvg.ro/index.php/studiaeconomia. Pages $69-91$ 
Botezat, E., Fotea, S.L., Marici, M., Fotea, I.S. (2020)

Fostering the mediating role of the feeling of belonging to an organization among Romanian members of Generation Z

Respondents were asked to indicate how important the six statements are for them when they are considering a potential job using this scale.

Table 1 Operationalization of career attitude concepts

\begin{tabular}{|c|c|}
\hline Construct & Items \\
\hline $\begin{array}{l}\text { Self-directed attitude }-8 \\
\text { items } \\
\text { (Briscoe et al., 2006; } \\
\text { Volmer \& Spurk, 2011) }\end{array}$ & $\begin{array}{l}\text { I am in charge of my own career } \\
\text { Ultimately, I depend on myself to move my career forward. } \\
\text { I am responsible for my success or failure in my career. } \\
\text { Where my career is concerned, I am very much "my own person." } \\
\text { Overall, I have a very independent, self-directed career. } \\
\text { In the past, I have relied more upon myself than others to find a } \\
\text { new job/internship when necessary. } \\
\text { Freedom to choose my own career path is one of my most } \\
\text { important values. } \\
\text { When development opportunities have not been offered by my } \\
\text { company, I've sought them out on my own. }\end{array}$ \\
\hline $\begin{array}{l}\text { Value-driven attitude }-5 \\
\text { items } \\
\text { (Briscoe et al., 2006; } \\
\text { Volmer \& Spurk, 2011) }\end{array}$ & $\begin{array}{l}\text { I'll follow my own guidance if my company/my job asks me to do } \\
\text { something that goes against my values. } \\
\text { In the past, I had sided with my own values when I was asked to do } \\
\text { something I didn't agree with. } \\
\text { What I think about what is right in my career is more important to } \\
\text { me than what others think. } \\
\text { It doesn't matter much to me how other people evaluate the choices } \\
\text { I make in my career. } \\
\text { What's most important to me is how I feel about my career success, } \\
\text { not how other people feel. }\end{array}$ \\
\hline $\begin{array}{l}\text { Boundaryless mindset } \\
\text { attitude }-6 \text { items } \\
\text { (Briscoe et al., 2006; } \\
\text { Volmer \& Spurk, 2011) }\end{array}$ & $\begin{array}{l}\text { I enjoy/would enjoy jobs that allow me to work with people outside } \\
\text { my organization. } \\
\text { I enjoy/would enjoy jobs that require me to interact with people in } \\
\text { many different organizations. } \\
\text { I like/would like tasks at work that require me to work beyond my } \\
\text { own department. } \\
\text { I enjoy/would enjoy working on projects with people from across } \\
\text { many organizations. } \\
\text { I am energized in new experiences and situations. } \\
\text { I seek jobs that allow me to learn something new. }\end{array}$ \\
\hline $\begin{array}{l}\text { Organizational mobility } \\
\text { preference attitude }-4 \\
\text { items } \\
\text { (Briscoe et al., 2006; } \\
\text { Volmer \& Spurk, 2011) }\end{array}$ & $\begin{array}{l}\text { If my current /future employer organization provided lifetime } \\
\text { employment, I would never desire to seek work in other } \\
\text { organizations. (R) } \\
\text { In my ideal career, I would work for only one organization. (R) } \\
\text { I like the predictability that comes with working continuously for } \\
\text { the same organization. (R) } \\
\text { I prefer to stay in a company I am familiar with rather than look for } \\
\text { employment elsewhere. (R) }\end{array}$ \\
\hline
\end{tabular}


Botezat, E., Fotea, S.L., Marici, M., Fotea, I.S. (2020)

Fostering the mediating role of the feeling of belonging to an organization among Romanian members of Generation Z

The Standardized Alpha Coefficient obtained for FBO scale was 0.818. The specific items used to operationalize these variables are presented in Table 2.

Table 2 Operationalization of feeling of belonging

\begin{tabular}{ll}
\hline Construct & $\begin{array}{l}\text { Items } \\
\text { How important are for you each of the following aspects in } \\
\text { your job/ when you are considering a job? }\end{array}$ \\
\hline Feeling of belonging to an & $\begin{array}{l}\text { To feel that I belong to the organization. } \\
\text { organization }-6 \text { items }\end{array}$ \\
$\begin{array}{l}\text { To feel comfortable in the organization/to be allowed to be me. } \\
\text { (Burr et al., 2010; Pejtersen }\end{array}$ & $\begin{array}{l}\text { To feel the organization is my second home. } \\
\text { et al., 2010). }\end{array}$ \\
& $\begin{array}{l}\text { To have a good atmosphere between you and your colleagues. } \\
\text { To have good co-operation between the colleagues at work. } \\
\text { To feel part of a community at your place of work. }\end{array}$ \\
\hline
\end{tabular}

We used three items to assess the Centennials' turnover intention (CTI), which was the dependent variable in our study, namely the constant search for new job opportunities, the periodic switch of jobs and the indefinite stay in a company. The respondents evaluated all three items on a Likert scale ranging from 1 (totally disagree) to 5 (totally agree). The Standardized Alpha Coefficient obtained for CTI scale 0.802 .

The final questionnaire consisted of three sections. The first, which is not part of this article, assessed the importance of various elements in the decision-making process of Centennials in their job search. The second part consisted of questions designed to evaluate the career attitude of respondents, their possible turnover intention, and the feeling of belonging to an organization. The last section was dedicated to collecting demographic data from participants.

\subsection{Participants and data collection}

To investigate our hypotheses, we collected data based on a sample of 1920 undergraduate and master students in economics from two universities located in the western part of Romania. The survey was constructed and disseminated using the specialized online platform Qualtrics. Two reminders followed the initial invitation email after 14 and 21 days, respectively. The data collection was carried out during February 2019. As a result of this process, a total of 414 students submitted their responses using the provided link. The participants in the study were predominantly undergraduates $(88.53 \%)$, female students $(66.66 \%)$, with limited work experience. The average age of our respondents was 22.57 years. Table 3 provides a summary of the demographic characteristics of our sample.

The participants in this study were informed from the very beginning about the purpose of the research, its expected duration, and procedures. They had the right to decline participation and even withdraw from the investigation once it had

78 Sciendo Studia Universitatis "Vasile Goldis" Arad. Economics Series Vol 30 Issue 4/2020 ISSN: 1584-2339; (online) ISSN: $2285-3065$

Web: publicatii.uvvg.ro/index.php/studiaeconomia. Pages $69-91$ 
Botezat, E., Fotea, S.L., Marici, M., Fotea, I.S. (2020)

Fostering the mediating role of the feeling of belonging to an organization among Romanian members of Generation Z

started. Also, participants' privacy and confidentiality were ensured by the fact that they filled in an anonymous questionnaire.

Table 3 Sample characteristics $(N=414)$

\begin{tabular}{|l|l|}
\hline Variable & Mean or \% \\
\hline Gender & \\
\hline Female & $66.66 \%$ \\
\hline Male & $33.33 \%$ \\
\hline Age (years) & 22.57 \\
\hline Education & \\
\hline Undergraduate & $88.53 \%$ \\
\hline Master & $11.46 \%$ \\
\hline Work experience & \\
\hline No/ Internships only & $42.2 \%$ \\
\hline 0-2 year & $41.5 \%$ \\
\hline At least 3 years & $15.7 \%$ \\
\hline
\end{tabular}

\section{Data Analysis and results}

To test the hypotheses H1-H4, we used PROCESS version 3.3 by Andrew F. Hayes (2018), with mediation model number four, SPSS, and Microsoft Excel. Firstly, a Pearson Correlation Analysis was performed, then all four mediation hypotheses were tested.

The Pearson Correlation matrix, which is presented in Table 4, indicates the significant relationships between the main variables in the analysis.

Table 4 Pearson Correlations between the Main Variables of the Research

\begin{tabular}{|l|l|l|l|l|l|l|}
\hline & $\begin{array}{l}\text { Centennials } \\
\text { turnover } \\
\text { intentions }\end{array}$ & $\begin{array}{l}\text { Feeling of } \\
\text { belonging to } \\
\text { organization }\end{array}$ & $\begin{array}{l}\text { Self- } \\
\text { directed } \\
\text { attitude }\end{array}$ & $\begin{array}{l}\text { Value- } \\
\text { driven } \\
\text { attitude }\end{array}$ & $\begin{array}{l}\text { Boundaryless } \\
\text { mindset } \\
\text { attitude }\end{array}$ & $\begin{array}{l}\text { Organizational } \\
\text { mobility } \\
\text { preference attitude }\end{array}$ \\
\hline $\begin{array}{l}\text { Centennials } \\
\text { turnover } \\
\text { intentions }\end{array}$ & -0.077 & $0.181 * *$ & $0.215^{* *}$ & $0.210^{* *}$ & 0.015 \\
\hline $\begin{array}{l}\text { Feeling of } \\
\text { belonging to } \\
\text { organization }\end{array}$ & & & $0.266^{* *}$ & $0.152^{* *}$ & $0.273 * *$ & $0.187 * *$ \\
\hline $\begin{array}{l}\text { Self-directed } \\
\text { attitude }\end{array}$ & & & & $0.422^{* *}$ & $0.498^{* *}$ & $0.216^{* *}$ \\
\hline $\begin{array}{l}\text { Value-driven } \\
\text { attitude }\end{array}$ & & & & & $0.303 * *$ & 0.057 \\
\hline $\begin{array}{l}\text { Boundaryless } \\
\text { mindset attitude }\end{array}$ & & & & & & 0.092 \\
\hline $\begin{array}{l}\text { Organizational } \\
\text { mobility } \\
\text { preference } \\
\text { attitude }\end{array}$ & & & & & & \\
\hline
\end{tabular}

**correlations are significant at 0.01 
Botezat, E., Fotea, S.L., Marici, M., Fotea, I.S. (2020)

Fostering the mediating role of the feeling of belonging to an organization among Romanian members of Generation Z

The results show that there are significant correlations between most of the variables in the matrix. The exception is the correlation between the Centennials' turnover intention, the feeling of belonging to an organization, and organizational mobility preference.

The analyses performed in PROCESS to test hypothesis 1 that "The feeling of belonging to an organization (FBO) mediates the relationship between self-directed attitude (SDA) and Centennials turnover intention (CTI)" indicated the following results (see Figure 2).

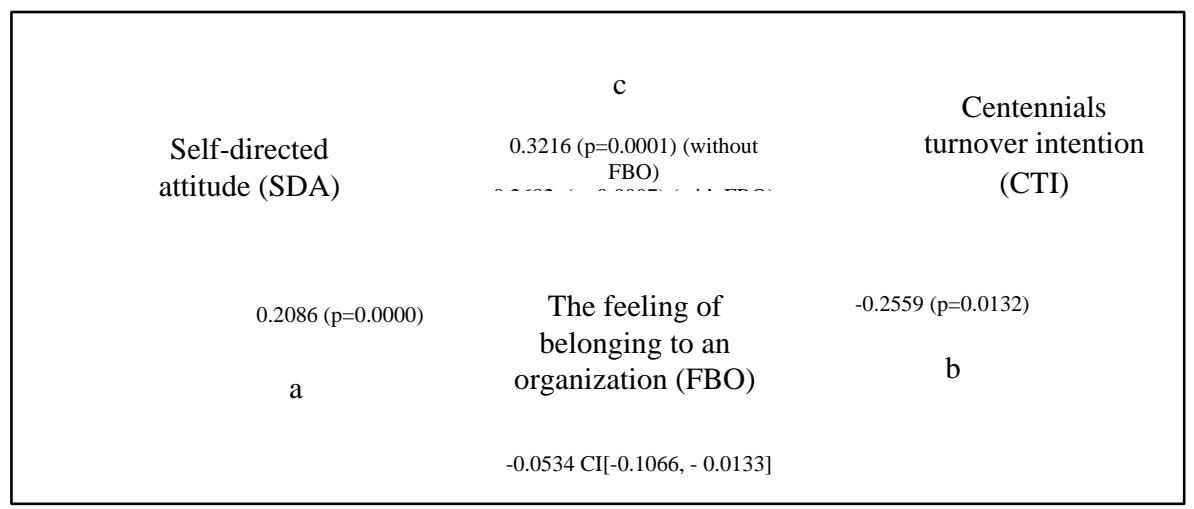

Figure 2 Results for the Mediation Model

All results for mediation were reported using the format of Kane and Ashbaugh (2017). Results from a simple mediation analysis indicated that a self-directed attitude is indirectly related to Centennials turnover intention through its relationship with the feeling of belonging to an organization. First, as can be seen in the figure above, respondents with a higher self-directed attitude reported a higher level of feeling of belonging to an organization $(a=0.2086, p=0.0000)$. Also, a higher reported feeling of belonging to an organization was subsequently related to less Centennials turnover intention $(b=-0.2559, p=0.0132)$. A $95 \%$ biascorrected confidence interval based on 10,000 bootstrap samples indicated that the indirect effect $(a b=-0.0534)$ was entirely below zero $(-0.1066$ to -0.0133$)$. Moreover, self-directed attitude respondents reported more Centennials turnover intention even after taking into account self-directed attitude indirect effect through the feeling of belonging to an organization ( $c=0.2682, \mathrm{p}=0.0007)$. Hypothesis $\mathrm{H} 1$ "The feeling of belonging to an organization mediates the relationship between self-directed attitude and Centennials turnover intention" is confirmed.

80 sciendo Studia Universitatis "Vasile Goldis" Arad. Economics Series Vol 30 Issue 4/2020 ISSN: 1584-2339; (online) ISSN: $2285-3065$

Web: publicatii.uvvg.ro/index.php/studiaeconomia. Pages $69-91$ 
Botezat, E., Fotea, S.L., Marici, M., Fotea, I.S. (2020)

Fostering the mediating role of the feeling of belonging to an organization among Romanian members of Generation Z

The analyses performed in PROCESS to test hypothesis 2 that "The feeling of belonging to an organization (FBO) mediates the relationship between value-driven attitude (VDA) and Centennials turnover intention (CTI)" indicated the following results (see Figure 3).

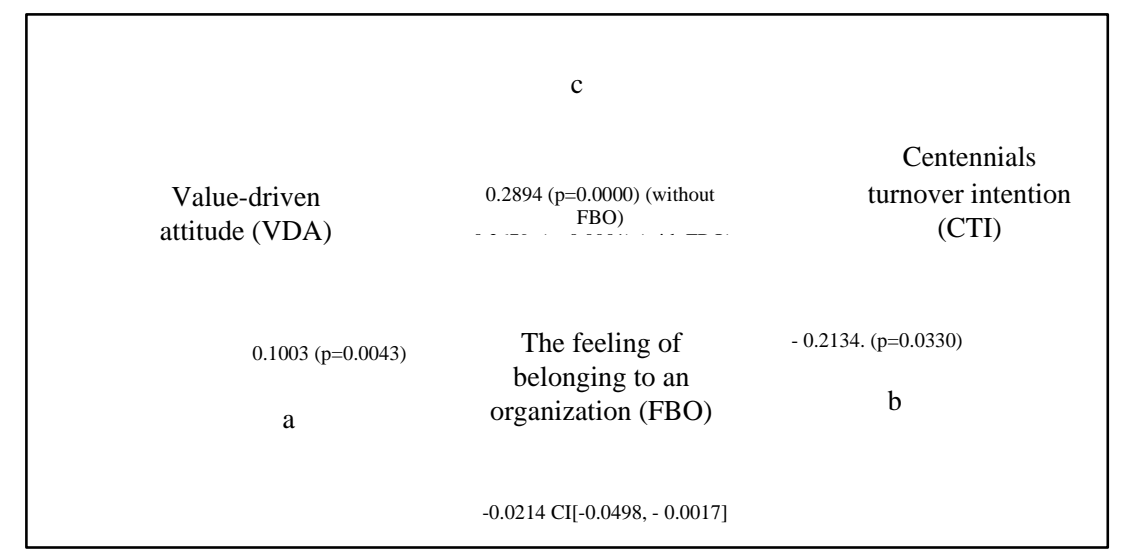

Figure 3 Results for the Mediation Model

Results from a simple mediation analysis indicated that a value-driven attitude is indirectly related to Centennials' turnover intention through its relationship with the feeling of belonging to an organization. First, as can be seen in Figure above, respondents with a higher value-driven attitude reported a higher level of feeling of belonging to an organization $(a=0.1003, p=0.0043)$, and more reported feeling of belonging to an organization was subsequently related to less Centennials' turnover intention ( $b=-0.2134, p=0.0330)$. A 95\% bias-corrected confidence interval based on 10,000 bootstrap samples indicated that the indirect effect $(a b=-0.0214)$ was entirely below zero (-0.0498 to -0.0017$)$. Moreover, value-driven attitude respondents reported more Centennials' turnover intention even after taking into account value-driven attitude indirect effect, through the feeling of belonging to an organization $(\mathrm{c}=0.2894, \mathrm{p}=0.0000)$. Hypothesis $\mathrm{H} 2$ "The relationship between value-driven attitude and Centennials turnover intention is mediated by the feeling of belonging to an organization" is thus confirmed.

The analyses performed in PROCESS, to test hypothesis 3 that "The feeling of belonging to an organization (FBO) mediates the relationship between boundaryless mindset attitude (BMA) and Centennials' turnover intention (CTI)" yielded the following results (see Figure 4).

Results from a simple mediation analysis indicated that boundaryless mindset attitude is indirectly related to Centennials' turnover intention through its 
Botezat, E., Fotea, S.L., Marici, M., Fotea, I.S. (2020)

Fostering the mediating role of the feeling of belonging to an organization among Romanian members of Generation Z

relationship with the feeling of belonging to an organization. First, as can be seen above in Figure 4, Centennials with a stronger boundaryless mindset attitude reported a higher level of feeling of belonging to an organization $(a=0.1886, p=$ 0.0000 ), and more reported feeling of belonging to an organization was subsequently related to less Centennials' turnover intention $(\mathrm{b}=-0.2756$, $\mathrm{p}=0.0073$ ).

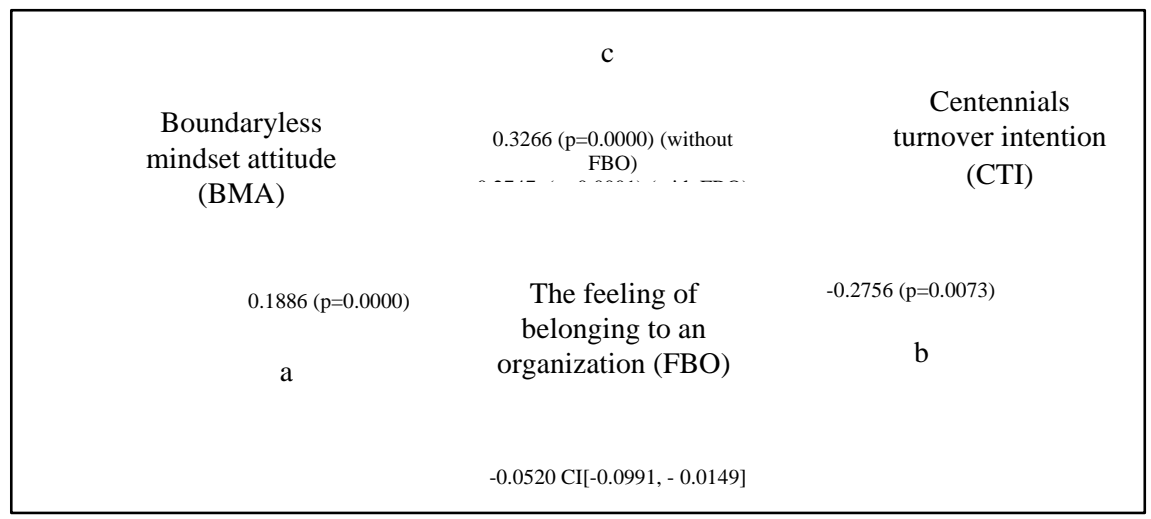

Figure 4 Results for the Mediation Model

A 95\% bias-corrected confidence interval based on 10,000 bootstrap samples indicated that the indirect effect $(\mathrm{ab}=-0.0520)$ was entirely below zero $(-0.0991$ to -0.0149). Moreover, boundaryless mindset attitude respondents reported more Centennials' turnover intention even after taking into account boundaryless mindset indirect effect through feeling of belonging to an organization $(\mathrm{c}=0.2747, \mathrm{p}=$ 0.0001). Hypothesis $\mathrm{H} 3$ "The feeling of belonging to an organization mediates the relationship between boundaryless mindset attitude and Centennials turnover intention" is thus confirmed.

The analyses performed in PROCESS, to test hypothesis 4 that "The feeling of belonging to an organization (FBO) mediates the relationship between organizational mobility preference attitude (OMPA) and Centennials' turnover intention (CTI)" indicated the following results (see Figure 5).

Results from a simple mediation analysis indicated that organizational mobility preference attitude is not indirectly related to Centennials' turnover intention through its relationship with the feeling of belonging to an organization. First, as can be seen in Figure 5, Centennials with a higher organizational mobility preference attitude reported a higher level of feeling of belonging to an organization $(\mathrm{a}=0.0997, \mathrm{p}=0.0004)$, and more reported feeling of belonging to an

82 Sciendo Studia Universitatis "Vasile Goldis" Arad. Economics Series Vol 30 Issue 4/2020 ISSN: 1584-2339; (online) ISSN: $2285-3065$

Web: publicatii.uvvg.ro/index.php/studiaeconomia. Pages $69-91$ 
Botezat, E., Fotea, S.L., Marici, M., Fotea, I.S. (2020)

Fostering the mediating role of the feeling of belonging to an organization among Romanian members of Generation Z

organization was subsequently not related to Centennials turnover intention $(b=-$ $0.1576, \mathrm{p}=0.1271$ ). A 95\% bias-corrected confidence interval based on 10,000 bootstrap samples indicated that the indirect effect $(a b=-0.0157)$ was including zero (-0.0387 to -0.0029$)$. Moreover, respondents with higher organizational mobility preference attitude did report more turnover intention even after taking into account the indirect effect through the feeling of belonging to an organization $(\mathrm{c}=0.2682, \mathrm{p}=0.0007)$. Hypothesis $\mathrm{H} 4$ "The relationship between organizational mobility preference attitude and Centennials turnover intention is mediated by the feeling of belonging to an organization" is not confirmed.

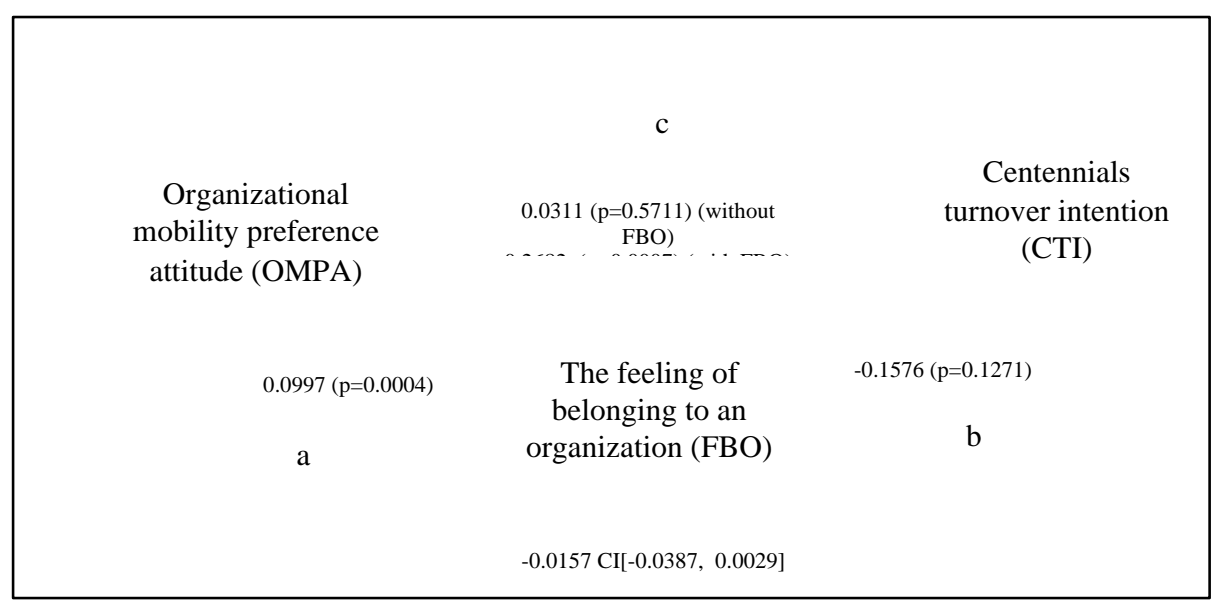

Figure 5 Results for the Mediation Model

To test hypothesis H5 "All four attitudinal variables are predictors of the feeling of belonging to an organization", we used Linear Hierarchical Regression in SPSS, Enter method. Through the present analysis, we could find how much variance from the feeling of belonging to an organization can be explained by the attitudinal variables and which of these have stronger explicative power. To broaden our understanding, we also included in this analysis three demographic variables, namely gender, age, and level of education. The results of the regression analysis are depicted in Table 5.

The analysis indicated that the fifth regression model, which includes predictor demographic variables and all four predictor attitudinal variables (self-directed attitude, value-driven attitude, boundaryless mindset attitude, and organizational mobility preference attitude), explain $15.1 \%$ of the total variance of feelings of belonging to the organization. This regression model has the highest score of all regression models. Thus, on one hand, gender and age of respondents are 
Botezat, E., Fotea, S.L., Marici, M., Fotea, I.S. (2020)

Fostering the mediating role of the feeling of belonging to an organization among Romanian members of Generation Z

significant demographic predictors for the variable feeling of belonging to an organization. The $\mathrm{t}$-test for independent variables show that females $(\mathrm{M}=4.61, \mathrm{SD}$ $=0.38$ ) report a higher score of the feeling of belonging to an organization than males $(\mathrm{M}=4.46, \mathrm{SD}=0.49,95 \% \mathrm{CI}$ : [0.0459, 0.2507]).

Table 5 Hierarchical Regression Analysis of Predictors of Feelings of Belonging to the Organization reported according to (Valenzuela et al., 2009).

\begin{tabular}{|c|c|c|c|c|c|}
\hline Predictor variables & $\begin{array}{l}\text { Regression } \\
\text { Model } 1\end{array}$ & $\begin{array}{l}\text { Regression } \\
\text { Model } 2\end{array}$ & $\begin{array}{l}\text { Regression } \\
\text { Model } 3\end{array}$ & $\begin{array}{l}\text { Regression } \\
\text { Model } 4\end{array}$ & $\begin{array}{l}\text { Regression } \\
\text { Model } 5\end{array}$ \\
\hline \multicolumn{6}{|l|}{ Demographic variables } \\
\hline Gender ( 1 - female, 2 male $)$ & $-0.157 * *$ & $-0.163 * * *$ & $-0.167 * * *$ & $-0.158 * *$ & $-0.151 * *$ \\
\hline Age & $-0.137 *$ & $-0.142 * *$ & $-0.140 * *$ & $-0.130 * *$ & $-0.131 * *$ \\
\hline $\begin{array}{l}\text { Level of education } \\
(1-\text { bachelor's degree, } \\
2-\text { masters' degree })\end{array}$ & -0.070 & -0.051 & -0.050 & -0.054 & -0.052 \\
\hline \multicolumn{6}{|l|}{ Attitudinal variables } \\
\hline Self-directed Attitude & & $0.275^{* * *} *$ & $0.253 * * *$ & $0.180 * *$ & $0.146^{*}$ \\
\hline Value-Driven attitude & & & 0.053 & 0.034 & 0.040 \\
\hline $\begin{array}{l}\text { Boundaryless mindset } \\
\text { attitude }\end{array}$ & & & & $0.160 * *$ & $0.163 * *$ \\
\hline $\begin{array}{l}\text { Organizational mobility } \\
\text { preference attitude }\end{array}$ & & & & & $0.144 * *$ \\
\hline $\mathrm{R} 2$ & 0.053 & 0.359 & 0.362 & 0.387 & 0.413 \\
\hline Adjusted R2 & 0.045 & 0.116 & 0.116 & 0.133 & 0.151 \\
\hline $\mathrm{R} 2$ change & $0.053 * * *$ & $0.075^{* * * *}$ & 0.002 & $0.019 * *$ & $0.020 * *$ \\
\hline $\begin{array}{l}* p<0.05, * * p<0.01, * * * \\
\text { All regression coefficients } \\
N=351\end{array}$ & $<0.001$ & indardized & & & \\
\hline
\end{tabular}

Pearson correlation indicates that the higher the age of respondents, the lower the score on the feeling of belonging to an organization $(\mathrm{N}=349, \mathrm{r}=-0.159, \mathrm{p}=$ 0.003 ). On the other hand, only three attitudinal variables were found as significant predictors for the feeling of belonging to an organization. These three are selfdirected attitude, boundaryless mindset attitude, and organizational mobility preference attitude. The value-driven attitude was not found as a significant predictor. Except for the demographic variables, Part Coefficients show how much would $\mathrm{R}^{2}$ decrease if the attitudinal variables are removed from the equation. Thus, comparing significant coefficients, the stronger predictor is organizational mobility preference attitude $\left(r_{\text {part }}=0.140\right)$, followed by boundaryless mindset attitude $\left(r_{\text {part }}=\right.$ $0.140)$, and self-directed attitude $\left(r_{\text {part }}=0.117\right)$. The hypothesis H5. "All four attitudinal variables are predictors of the feeling of belonging to an organization" is partially confirmed. 
Botezat, E., Fotea, S.L., Marici, M., Fotea, I.S. (2020)

Fostering the mediating role of the feeling of belonging to an organization among Romanian members of Generation Z

\section{Conclusions, limitations and future studies}

The present study aimed to analyze the potential mediating role of the feeling of belonging to an organization between four distinct career attitudes and the possible turnover intention in the specific case of Romanian Generation $\mathrm{Z}$ members, also known as Centennials. Additionally, we investigated which variables are significant predictors for the feeling of belonging to an organization.

The results show that the feeling of belonging to an organization is a significant mediator for the relationship between three distinct career attitudes: (1) selfdirected attitude (SDA); (2) value-driven attitude (VDA); (3) boundaryless mindset attitude (BMA), and Centennials turnover intention. In the case of organizational mobility preference attitude - OMPA (the fourth career attitude), the variable feeling of belonging to an organization does not mediate the influence to Centennials' turnover intention. Additionally, we found that self-directed attitude, boundaryless mindset attitude, and organizational mobility preference attitude are significant predictors for the feeling of belonging to an organization within Romanian Generation Z/Centennial members. Comparing significant coefficients, the strongest predictor is organizational mobility preference attitude (OMPA), followed by a boundaryless mindset attitude (BMA) and self-directed attitude (SDA).

We refrain from advancing comparisons of our findings with the results of other studies. Instead, we favor a possible explanation concerning these findings. Perhaps, in the environment where this study was conducted, some types of work had become very site-specific, leaving Generation $\mathrm{Z}$ members with the feeling that their person was limited by the employment market. However," success in the workplace demands the ability to function as a team member within highly complex social systems" (Igel \& Urquhart, 2012, p. 20), and for Generation Z members, one keyword is an affective concern. In a way, these are in line with Kartika \& Purba's (2018) results, which shows that affective commitment to an organization can have the greatest effect on organizational outcomes compared to normative and continuance commitment. Our study proposes an alternative view of the motivational potential, including the feeling of belonging to an organization in work settings in the case of Generation $\mathrm{Z}$ members. This seems to work for those Generation $\mathrm{Z}$ members inclined towards making moves between jobs and organizations (OMPA), for those who present the mental capacity to be mobile (BMA) and for those who can be adaptive in terms of performance and learning demands (SDA). For those Romanian Generation $\mathrm{Z}$ members who use their internal values to provide guidance and measure for success, including the feeling of belonging to an organization in work settings seems to be inefficient. 
Botezat, E., Fotea, S.L., Marici, M., Fotea, I.S. (2020)

Fostering the mediating role of the feeling of belonging to an organization among Romanian members of Generation Z

Our research has focused on a key psychological trait - the feeling of belonging to an organization within Generation Z/Centennial members, as a future addition to the workplace landscape. Generally, this psychological trait was analyzed in association with employees who, as we know, are, for the most part, members of all the other generations before Generation Z/Centennials. Thus, our study contributes to the broadening of the understanding regarding Generation Z/Centennials' specific sets of behaviors as well as unique expectations at work.

The main managerial implication of our results is that much more must be done to respond to Generation Z's need for experiencing belongingness. Among the frequently emphasized priorities mentioned by scholars and practitioners are attractive earnings, guidance and support, work independence, work meaningfulness, and personal utility value. More detailed studies should identify more clearly the role of the feeling of belonging to an organization within Generation Z/Centennials.

The main limitations of this research lie in several facts: (1) the analysis of collected data is static and geographically limited and does not provide insight into changes of attitude over time and space; (2) the survey-based empirical exploratory study was conducted based on self-reported data, and (3) the sample can be considered relatively narrow.

The value of the paper lies in approaching a current and relatively new subject in management literature, in the context of a lack of economic or organizational oriented research. Moreover, it draws attention to a current issue existing in Romanian organizations, namely that of a lack of a young workforce. We deem that taking into consideration the feeling of belonging to an organization is an appropriate mediator between Centennials' career attitude and their turnover intention. This can further aid managers in making strategically successful decisions.

This research can be considered a starting point in developing a framework to understand how the next generation, Generation Z/Centennials, thinks about work, career, and workplace. The research can be continued on a larger sample. A comparison between individuals from different countries could be of interest to emphasize the similarities and differences and to broaden the understanding of Generation $Z^{\prime}$ behavior in organizations.

\section{Acknowledgments}

The authors thank the anonymous reviewers and editor for their valuable contribution.

86 Sciendo Studia Universitatis "Vasile Goldis" Arad. Economics Series Vol 30 Issue 4/2020 ISSN: 1584-2339; (online) ISSN: $2285-3065$

Web: publicatii.uvvg.ro/index.php/studiaeconomia. Pages $69-91$ 
Botezat, E., Fotea, S.L., Marici, M., Fotea, I.S. (2020)

Fostering the mediating role of the feeling of belonging to an organization among Romanian members of Generation Z

\section{Funding}

This research received no specific grant from any funding agency in the public, commercial, or not - for - profit sectors.

\section{Author Contributions}

EB and SF designed the study and were responsible for the operationalization of variables, the literature review and the conclusion sections of the paper. IF was responsible for data collection and $\mathrm{MM}$ was responsible for the analysis of the data.

\section{Disclosure Statement}

The authors have not any competing financial, professional, or personal interests from other parties.

\section{References}

1. Arthur, M.B., (1994), The boundaryless career: A new perspective for organizational inquiry, Journal of Organizational Behavior, 15(4), pp. 295-306. https://doi.org/10.1002/job.4030150402

2. Arthur, M.B., Hall, D.T., Lawrence, B.S., (1989), Handbook of career theory, Cambridge University Press. https://doi.org/10.1017/CBO9780511625459

3. Arthur, M.B., Rousseau, D.M., (2001), The Boundaryless Career: A New Employment Principle for a New Organizational Era (New Ed edition), Oxford University Press

4. Awan, A.G., Anjam, K.U., (2014), Employees Turnover Rate in Oil Refineries: A Case Study of Pak Arab Refinery Ltd (PARCO), Global Journal of Human Resource Management, 2(3), pp. 73-86

5. Baumeister, R.F., Leary, M.R., (1995), The need to belong: Desire for interpersonal attachments as a fundamental human motivation, Psychological Bulletin, 117(3), pp. 497-529. https://doi.org/10.1037/0033-2909.117.3.497

6. Bers, T.H., Smith, K.E., (1991), Persistence of Community College Students: The Influence of Student Intent and Academic and Social Integration, Research in Higher Education, 32(5), pp. 539-556. JSTOR

7. Blais, M., Zerpa Pulido, A., (1992), Family, social life and leisure: Cultural differences among university students in Caracas and in Montreal, McGill Journal of Education, 27(2), pp. 150-164

8. Briscoe, J.P., Hall, D.T., (2006), The interplay of boundaryless and protean careers: Combinations and implications, Journal of Vocational Behavior, 69(1), pp. 4-18. https://doi.org/10.1016/j.jvb.2005.09.002 
Botezat, E., Fotea, S.L., Marici, M., Fotea, I.S. (2020)

Fostering the mediating role of the feeling of belonging to an organization among Romanian members of Generation Z

9. Briscoe, J.P., Hall, D.T., Frautschy DeMuth, R.L., (2006), Protean and boundaryless careers: An empirical exploration, Journal of Vocational Behavior, 69(1), pp. 30-47. https://doi.org/10.1016/j.jvb.2005.09.003

10. Buhler, P., Evans, N., (2018), Will Gen Z Want to Work for You? Human Resource Executive. http://hrexecutive.com/will-gen-z-want-work/

11. Burr, H., Albertsen, K., Rugulies, R., Hannerz, H., (2010), Do dimensions from the Copenhagen Psychosocial Questionnaire predict vitality and mental health over and above the job strain and effort-Reward imbalance models?, Scandinavian Journal of Public Health, 38(3), pp. 59-68. https://doi.org/10.1177/1403494809353436

12. Chicca, J., Shellenbarger, T., (2018), Generation Z: Approaches and TeachingLearning Practices for Nursing Professional Development Practitioners, Journal for Nurses in Professional Development, 34(5), pp. 250-256. https://doi.org/10.1097/NND.0000000000000478

13. Deci, E.L., Ryan, R.M., (1991), A motivational approach to self: Integration in personality, in Current theory and research in motivation (Vol. 38, pp. 237-288). University of Nebraska Press

14. Defillippi, R.J., Arthur, M.B.. (1994), The Boundaryless Career: A Competency-Based Perspective, Journal of Organizational Behavior, 15(4), pp. 307-324. JSTOR

15. Dodescu, A.O., Botezat, E.A., Constăngioară, A., Boloș, M.I., (2018), An Exploratory Analysis of the Territorial Capital and Economic Growth: Evidence from Romania, Economic Computation and Economic Cybernetics Studies and Research, 52(4), pp. 95-112. https://doi.org/10.24818/18423264/52.4.18.07

16. Feldman, D.C., Leana, C.R., (2000), What Ever Happened to Laid-Off Executives? A Study of Reemployment Challenges after Downsizing, Organizational Dynamics, 29(1), pp. 64-75

17. Ferincz, A., Hortovanyi, L., Szabó, R., Taródy, D., (2011), Changes in the way of work: Generation " $Z$ " at the labour market

18. Fox, C., (2016,). Generation Snowflake: How we train our kids to be censorious cry-babies, The Spectator. https://www.spectator.co.uk/2016/06/ generation-snowflake-how-we-train-our-kids-to-be-censorious-cry-babies/

19. Gaidhani, S., Arora, D.L., Sharma, B.K., (2019), Understanding the attitude of Generation $Z$ towards workplace, International Journal of Management, Technology And Engineering, IX(I), 2804-2011

20. Gherini, A., (2018), Gen-Z Is About to Outnumber Millennials. Here's How That Will Affect the Business World, Inc.Com. https://www.inc.com/annegherini/gen-z-is-about-to-outnumber-millennials-heres-how-that-will-affectbusiness-world.html

88 Studia Universitatis "Vasile Goldis" Arad. Economics Series Vol 30 Issue 4/2020 ISSN: 1584-2339; (online) ISSN: 2285 - 3065

Web: publicatii.uvvg.ro/index.php/studiaeconomia. Pages $69-91$ 
Botezat, E., Fotea, S.L., Marici, M., Fotea, I.S. (2020)

Fostering the mediating role of the feeling of belonging to an organization among Romanian members of Generation Z

21. Hall, D.T., (1976), Careers in Organizations. Scott Foresman \& Co

22. Hall, D.T., (2004), The protean career: A quarter-century journey, Journal of Vocational Behavior, 65(1), pp. 1-13. https://doi.org/10.1016/j.jvb.2003.10.006

23. Hayes, A., (2018), Introduction to Mediation, Moderation, and Conditional Process Analysis, Second Edition: A Regression-Based Approach 2nd New edition (2nd ed.). Guilford Publications. https://www.kriso.ee/introduction-mediationmoderation-conditional-process-analysis-db-9781462534654.html

24. Igel, C., \& Urquhart, V., (2012), Generation Z, Meet Cooperative Learning, Middle School Journal (J3), 43(4), pp. 16-21

25. Inkson, K., (2008), Are humans resources? Career Development International, 13(3), pp. 270-279. https://doi.org/10.1108/13620430810870511

26. Insider, B., (2018), Generation Z: Latest Gen Z News, Research, Facts \& Strategies, Business Insider. https://www.businessinsider.com/generation-Z

27. Jha, S., (2009), Determinants of Employee Turnover Intentions: A Review, Management Today, 9(2), pp. 26-33

28. Kane, L., Ashbaugh, A.R., (2017), Simple and parallel mediation: $\{A\}$ tutorial exploring anxiety sensitivity, sensation seeking, and gender, The Quantitative Methods for Psychology, 13(3), 148-165. https://doi.org/10.20982/tqmp.13.3.p148 29. Kartika, G., Purba, D.E., (2018), Job satisfaction and turnover intention: The mediating effect of affective commitment, Psychological Research on Urban Society, 1(2), pp. 100-106. https://doi.org/10.7454/proust.v1i2.34

30. Kelly, K.M., (2001), Individual differences in reactions to rejection, In Interpersonal Rejection (pp. 291-315). Oxford University Press

31. Lee, M.C.C., Idris, M.A., Tuckey, M., (2019), Supervisory coaching and performance feedback as mediators of the relationships between leadership styles, work engagement, and turnover intention, Human Resource Development International, 22(3), pp. 257-282. https://doi.org/10.1080/13678868.2018.1530170 32. Martin, J., Schmidt, C., (2010), How to Keep Your Top Talent, Harvard Business Review, 88(5), pp. 54-61

33. Maslow, A.H. (1968). Toward a psychology of being, D. Van Nostrand Company

34. Miller, L.J., Lu, W., (2018), Gen Z Is Set to Outnumber Millennials Within a Year, Bloomberg.com. https://www.bloomberg.com/news/articles/2018-08-0/genz-to-outnumber-millennials-within-a-year-demographic-trends

35. Parasuraman, S., (1989), Nursing turnover: An integrated model, Research in Nursing \& Health, 12(4), pp. 267-277. https://doi.org/10.1002/nur.4770120409

36. Paunescu, C., Molnar, E., (2016), Perspective privind dinamica pieţei muncii şi implicaţiile acesteia asupra învăţământului superior, Review of Management \& Economic Engineering, 15(4), pp. 637-648 
Botezat, E., Fotea, S.L., Marici, M., Fotea, I.S. (2020)

Fostering the mediating role of the feeling of belonging to an organization among Romanian members of Generation Z

37. Pejtersen, J.H., Kristensen, T.S., Borg, V., Bjorner, J.B., (2010), The second version of the Copenhagen Psychosocial Questionnaire, Scandinavian Journal of Public Health, 38(3_suppl), pp. 8-24. https://doi.org/10.1177/1403494809349858 38. Price, J.L., Mueller, C.W., (1981), A Causal Model of Turnover for Nurses, Academy of Management Journal, 24(3), pp. 543-565. https://doi.org/10.5465/255574

39. Riaz, A.M., Amanat, A.J,. (2013), Mediation of Work Engagement between Emotional Exhaustion, Cynicism and Turnover Intentions, International Journal of Management Sciences and Business Research, 2(7), pp. 45-54

40. Rigby, C.S., Ryan, R.M., (2018), Self-Determination Theory in Human Resource Development: New Directions and Practical Considerations, Advances in Developing Human Resources, 20(2), pp. 133-147. https://doi.org/10.1177/1523422318756954

41. Shemueli, R.G., Dolan, S.L., Ceretti, A.S., Prado, P.N. del., (2016), Burnout and Engagement as Mediators in the Relationship between Work Characteristics and Turnover Intentions across Two Ibero-American Nations, Stress and Health, 32(5), pp. 597-606. https://doi.org/10.1002/smi.2667

42. Spears, J., Zobac, S.R., Spillane, A., Thomas, S., (2015), Marketing Learning Communities to Generation Z: The importance of face-to-face interaction in a digitally driven world, Learning Communities Research and Practice, 3(1), 12

43. Sullivan, S.E., Baruch, Y., (2009), Advances in Career Theory and Research: A Critical Review and Agenda for Future Exploration, Journal of Management, 35(6), pp. 1542-1571. https://doi.org/10.1177/0149206309350082

44. Syed, A., Ahmad, M.B., Ali, H.F., Arif, M.M., Gohar, A., (2018), WorkFamily Conflict and Turnover Intentions: Moderated Mediation Model, Human Resource Research, 2(1), pp. 95-106. https://doi.org/10.5296/hrr.v2i1.13925

45. Turner, A., (2015), Generation Z: Technology and Social Interest, Journal of Individual Psychology, 71(2), pp. 103-113

46. Udechukwu, I.I., Mujtaba, B.G., (2007), Determining the Probability That an Employee Will Stay or Leave the Organization: A Mathematical and Theoretical Model for Organizations, Human Resource Development Review, 6(2), pp. 164184. https://doi.org/10.1177/1534484307300239

47. Valenzuela, S., Park, N., Kee, K.F., (2009), Is There Social Capital in a Social Network Site?: Facebook Use and College Students' Life Satisfaction, Trust, and Participation, Journal of Computer-Mediated Communication, 14(4), pp. 875-901. https://doi.org/10.1111/j.1083-6101.2009.01474.x

48. Volmer, J., Spurk, D., (2011), Protean and boundaryless career attitudes: Relationships with subjective and objective career success, Zeitschrift Für

90 S sciendo Studia Universitatis "Vasile Goldis" Arad. Economics Series Vol 30 Issue 4/2020 ISSN: 1584-2339; (online) ISSN: $2285-3065$

Web: publicatii.uvvg.ro/index.php/studiaeconomia. Pages $69-91$ 
Botezat, E., Fotea, S.L., Marici, M., Fotea, I.S. (2020)

Fostering the mediating role of the feeling of belonging to an organization among Romanian members of Generation Z

ArbeitsmarktForschung, 43(3), pp. 207-218. https://doi.org/10.1007/s12651-010$0037-$

49. WEF, (2016), The Future of Jobs Report 2018, (Centre for the New Economy and Society, p. Cologny/Geneva Switzerland) [Annual]. World Economic Forum. http://www3.weforum.org/docs/WEF_Future_of_Jobs_2018.pdf

50. Wiedmer, T., (2015), Generations Do Differ: Best Practices in Leading Traditionalists, Boomers, and Generations $X, Y$, and $Z$, Delta Kappa Gamma Bulletin, 82(1), 51

51. Xiong, Z., Ye, J., Wang, P., (2017), Psychological Contract and Turnover Intention of Dispatched Employees: Mediating Effects of Job Satisfaction and Organizational Commitment, Revista de Cercetare şi Intervenţie Socială, 56, pp. $19-43$

52. Youssef, C.M., Luthans, F., (2007), Positive Organizational Behavior in the Workplace: The Impact of Hope, Optimism, and Resilience, Journal of Management, 33(5), pp. 774-800. https://doi.org/10.1177/0149206307305562 